\title{
Intersections
}

Canadian Journal of Music

Revue canadienne de musique

\section{Murray Dineen. 2011. Friendly Remainders: Essays in Musical Criticism after Adorno. Montreal and Kingston: McGill-Queen's University Press. xi, 248 pp. ISBN 978-0-7735-3884-9 (hardcover), ISBN 978-0-7735-3919-8 (paperback)}

\section{Sherry Lee}

Volume 33, numéro 1, fall 2012

URI : https://id.erudit.org/iderudit/1025560ar

DOI : https://doi.org/10.7202/1025560ar

Aller au sommaire du numéro

Éditeur(s)

Canadian University Music Society / Société de musique des universités canadiennes

ISSN

1911-0146 (imprimé)

1918-512X (numérique)

Découvrir la revue

Citer ce compte rendu

Lee, S. (2012). Compte rendu de [Murray Dineen. 2011. Friendly Remainders:

Essays in Musical Criticism after Adorno. Montreal and Kingston:

McGill-Queen's University Press. xi, 248 pp. ISBN 978-0-7735-3884-9

(hardcover), ISBN 978-0-7735-3919-8 (paperback)]. Intersections, 33(1), 110-113.

https://doi.org/10.7202/1025560ar

Copyright ( C Canadian University Music Society / Société de musique des universités canadiennes, 2014
Ce document est protégé par la loi sur le droit d'auteur. L'utilisation des services d'Érudit (y compris la reproduction) est assujettie à sa politique d'utilisation que vous pouvez consulter en ligne.

https://apropos.erudit.org/fr/usagers/politique-dutilisation/ 
et/ou sections individuelles, mais qui se déploie tout au long du livre, les thèmes permettent aux lecteurs de comprendre 1) les causes et les conséquences de la recherche entreprise par domaine et 2) la nécessité de l'interaction entre divers domaines. Un autre point fort concerne la rédaction même des articles. Chaque auteur débute son chapitre en présentant l'état actuel de son sujet de recherche, introduisant ainsi les noms d'autres chercheurs actifs dans le domaine. Puis, il termine en mentionnant les contraintes de la recherche et les développements futurs nécessaires ouvrant ainsi le champ des possibles. Dans leur conclusion, les directeurs de cet ouvrage collectif, Juslin et Sloboda, exposent leur souhait de faire progresser la recherche sur la musique et les émotions en discutant les trois aspects qui, selon les collaborateurs, devraient être traités dans les cinq années à venir et auraient un impact majeur sur l'amélioration et l'avancement de la recherche sur la musique et les émotions.

Deux propositions ont capté mon attention lors de la lecture de cet ouvrage: les styles de musique et les méthodes d'analyse. Ceux-ci n’ont pas été suffisamment abordés par les auteurs et mériteraient une plus grande attention. En effet, l'application de la recherche actuelle, notamment les moyens de mesure, à un contexte élargi serait tout à fait profitable aux élaborations futures. Je fais ici référence à une plus grande inclusion des cultures musicales autres qu'occidentales. Un autre bénéfice proviendrait de la constante attention prêtée à l'interaction entre les tests produits dans un environnement scientifique (ex. laboratoire) et un environnement quotidien (ex. discussion, concert). Ceci étant dit, cet ouvrage demeure une excellente référence dans le domaine autant pour les chercheurs que les étudiants à l'université.

Milada Medinić-Kazazić

Murray Dineen. 2011. Friendly Remainders: Essays in Musical Criticism after Adorno. Montreal and Kingston: McGill-Queen's University Press. xi, 248 pp. ISBN 978-0-7735-3884-9 (hardcover), ISBN 978-0-7735-3919-8 (paperback).

Eleven years have passed since the Adorno centennial. The years leading up to that historical marker saw escalated attention to Adorno's writings across disciplines but notably within musicological and music-theoretical circles in North America, where previously his work had been largely neglected or simply unknown. Since 2003, publications on Adorno have continued to proliferate-he remains widely recognized as one of the most important and controversial thinkers of the twentieth century. But although attention to Adorno continues apace in other disciplines, North American music scholarship is noticeably trend-driven in many quarters, so while significant and admirably refined considerations of his musical thought continue to appear, it is being given far less air time by music scholars who seem to feel that, having dealt with Adorno now, it is safe to move on. Unfortunately, in musical-scholarly circles, Adorno's writings devoted specifically to music were focused upon to the virtual exclusion of the rest of his work, including the very major texts; 
and even within those limitations he has been much more quoted than really studied. It has proven easier to extract pithy aphorisms (and there are so many) from those knotty texts than to engage them; easier also to bristle with indignation at the intellectual elitism their difficulty is supposed to manifest, and then to set them aside altogether, as if on principle.

Murray Dineen's Friendly Remainders: Essays in Musical Criticism after Adorno, then, stands out in several respects. It grapples not only with Adorno's music criticism but centrally with his Negative Dialectics, a key text that remains lesser known among music scholars, and one for which we still have only a less-than-adequate English translation (word is that Robert Hullot-Kentor is working on a new translation but we are still waiting for it to appear). Further, Dineen's book comes not only "after Adorno" himself but after the first flurry of North American music scholarship's initial engagement with his writings. It serves therefore as a welcome reminder that we have not yet "done" Adorno, but it is also thus positioned to take a reflective stance on what has, or has not, been done so far. It is a well-considered and evidently long-considered study. The latter remark is not backhanded but points to a quality evident throughout the text, which bespeaks a long engagement: a sense of having lived with Adorno's difficult, often thorny, but ultimately rewarding thought; a sense of familiarity, yes, but entirely without the numbing aspect of cosiness. It is also manifestly a highly composed book, one that exhibits a finely wrought sense of form and of working out, with sincerity-which is not to say always with seriousness, because there is welcome humour here-and simultaneously without pretension. Further, it is a remarkably personal piece of work, overtly and consciously so (of course, Adorno's writings are notably personal, too). Traces of both these latter features are evident on multiple levels: in the use of "after Adorno" as not only a guiding rubric but a textual leitmotif; in the carefully drawn connections between chapters, most of which nevertheless stand on their own for reading as essays; in the codas to select chapters that are, as the author notes, somewhat like Adorno's own Minima moralia, and yet simultaneously not like them, really rather like Dineen (including the final one featuring the author as a latter-day Orpheus with an accordion and Hades as a kind of cheap motel-moralia plus minima "nicely" encapsulated through juxtapositions of the mundane with the monumental).

Friendly Remainders represents a bold endeavour. It tackles real difficulties, including, as already mentioned, Adorno's sometimes daunting yet pivotally influential Negative Dialectics, and also the fraught issue of popular music criticism via an Adornian model, not to mention a strikingly broad range of subjects from Beethoven, Wagner, and Schoenberg through Coltrane, Zappa, and Marilyn Manson. Adorno himself should be added to this list, along with questions of (the) musical work, the relationship of the logic of the commodity to identity thinking, Mahler and figure skating, and dimensions of "technique" ranging from musical form and notation through the structure of Adorno's prose. All this is negotiated with impressive fluidity. That said, it is executed entirely without bravura; in fact, its tone and claims are made with a modesty that those who know Dineen personally will recognize as characteristic, and 
as a result, the book treads lightly enough that fairly careful reading, rather than thumbing-through, is required to recognize that it constitutes a weightier achievement than the author is likely to claim for himself. This lightness of approach, which serves well rather than trivializing its often-heavy subjects, is evident from the title onward and is obviously deliberate, but it is not the book's primary quality. What is evident throughout, rather, is Dineen's sense of responsibility in approaching, from a similar position yet without a falsely levelling stance, several diverse topics of real import that have often simply been left aside by previous scholarship. The book is concerned with materialities, with class consciousness, with tyranny, with political praxis, with work(s) and commodities, with the possibility for criticism today, and with the state of music scholarship and responsible discourse. In short (pun intended-it isn't an overly long volume), this book accomplishes quite a bit.

Serious scholars of Adorno have grown tired of the accusations of Adorno's elitism and his "dismissal" of popular culture-many have protested and probably just as many have chosen, finally, simply to ignore them-but Dineen manages to find a completely clear and straightforward way of articulating why these accusations ring so false. This is not to suggest that, in turning his attention to a fuller engagement with products of contemporary popular culture, Dineen is merely picking up Adorno's own project and extending it along the lines that the Frankfurt school philosopher and musicologist would have taken himself, if only he had lived long enough to hear some of this music with his own ears (an approach that has been tried by others and has proven both tired and tiresome). "What would Adorno say?" is manifestly not the guiding rubric here. One of the important questions Dineen does ask, though, is what can be offered by taking up Adornian thought, not merely to examine it for the perspectives it offers, but also to try it as an effective process for active critique of post-Adornian contexts and objects. His answer to this question is that quite a bit can be yielded by seeking out tensions and contradictions that signify-often something important-even within objects that first appear insignificant to many. Quite a few would readily acknowledge profundity in Coltrane and triviality in Rodgers and Hammerstein, without worrying much about what significance lies in the multiple discrepancies between them; many would probably wish to dismiss Marilyn Manson outright, but the materiality of the Columbine shooting is not so easy to brush aside.

Adorno's negative dialectic is both Dineen's focus and the lens through which he in turn views his chosen objects, some of which were also chosen by Adorno, others of which were certainly not (and, historically, could not have been), and one of which is sometimes Adorno himself. With gratifying clarity Dineen displays the workings of the negative dialectic on the small scale, highlighting instances within individual statements wherein Adorno's thought turns back on itself, creating what might initially appear to be a self-contradiction but is in fact, and critically, the deliberate enactment of the very possibility of critique, of thought thinking against itself. The author is bold enough to admit that the "remainder" that serves as both his title and his central motif is essentially a mistranslation—maybe better, an over-translation—from E. B. Ashton's 1973 
English rendering of Negativ Dialektik, Adorno's major opus on metaphysics and epistemology. This is no misstep nor a pretentiously postmodernist "misreading," but a critical interpretive gesture that Dineen not only justifies but employs to welcome explanatory effect. Ultimately, the logic of the remainder is as convincing as, but more applicable here than, that of the Derridean supplement (1976), to which it bears some structural resemblance.

By the time the book's conclusion is reached, another logic may gradually become evident to the reader who knows Adorno already, although it isn't part of Dineen's explicit agenda, and that is the way in which the work of critique is operating here through a principle that adheres to Adorno's notion of mimesis, an operator arguably as crucial in his enterprise as was that of the dialectic itself. For Adorno, the vital aspect of the mimetic impulse is the way in which it assimilates itself to its object, and in doing so, effectively resists the conceptual in its approach to the object: this is one of art's qualities that enables it to operate outside dominating modes of rationalist thought, and it (along with narrative) is a deliberately adopted mode found within Adorno's writing. Because Adorno's writing is itself an object for Dineen, he considers the substance of that trace-what literally (materially) remains after Adorno-and takes it as a model for his own project in a way that is attuned to Adorno's critique but also like it, yet without really attempting to mimic it (mimesis is not mimicry) - an impossible goal, even if it were desirable (Dineen notes this clearly), not only for the obvious and trivial reasons but for the more important linguistic, the cultural, and historical ones. In this way he manages to engage, through a process that is serious and in a tone that is relaxed, with objects that have slipped past the notice of many Adorno scholars, while developing a critical trajectory that continues Adorno's resistance to identity thinking and his protest against the use of music as distraction in an oppressively administered world.

If this review has focused mostly on the positioning of the book and the nature of Dineen's task and achievement, while avoiding the customary teasers and spoilers where content is concerned, it does so to convey the conviction that the book should not be read about, but read itself. What's more, this is far from an onerous assignment: Friendly Remainders has a distinct charm, and it goes a long way in showing just how very positive a little (or even a lot of) negativity can be.

\section{REFERENCES}

Adorno, Theodor W. 1973. Negative Dialectics, trans. E. B. Ashton. New York: Seabury.

Derrida, Jacques. 1976. Of Grammatology, trans. Gayatri C. Spivak. Baltimore: Johns Hopkins University Press. 